\title{
MINIREVIEW
}

\section{Antiviral therapy and prevention against hantavirus infections}

\author{
R. SZABÓ
}

\begin{abstract}
Institute of Virology, Biomedical Research Center Slovak Academy of Sciences, Dúbravská cesta 9, 84505 Bratislava, Slovak Republic; Comenius University in Bratislava, Faculty of Natural Sciences, Bratislava, Slovak Republic; University of Cagliari, Department of Biomedical Sciences, Monserrato (CA), Italy
\end{abstract}

\begin{abstract}
Summary. - Hantaviruses are emerging zoonoses hosted by small mammals. In humans, they cause two diseases. Hemorrhagic fever with renal syndrome is mainly caused by Dobrava-Belgrade virus, Puumala virus, Seoul virus and Hantaan virus in Asia and Europe. On the other hand, the most important causes of hantavirus cardiopulmonary syndrome are Sin Nombre virus and Andes virus in Americas. Ribavirin yet remains the only licensed drug against the hantavirus infections, but its sufficient antiviral activity remains an issue under discussion. There are still no available vaccines against hantaviruses except of some inactivated virus vaccines licensed only in East-Asian countries. Some of the vaccines are under development in pre-clinical stages. The review discuses about specific compounds with approved antiviral activity against hantaviruses. Other approaches such as development of vaccines, are compiled as well.
\end{abstract}

Keywords: hantavirus; HFRS; HCPS; antiviral drugs; vaccines

\section{Contents:}

1. Introduction

2. Virus-targeting antivirals

2.1 Ribavirin

2.2 Lactoferrin

2.3 Favipiravir

2.4 ETAR

2.5 Virus fusion inhibition

2.6 Immunotherapy

3. Host targeting antivirals
3.1 Corticosteroid therapy

3.2 Host-cell hantavirus-binding receptor inhibitors

3.3 Therapy via blocking of bradykinin B2 receptor

4. Vaccines

4.1 Inactivated virus vaccines

4.2 Chimeric molecular vaccines

4.3 Virus-like particles

4.4 DNA vaccines

5. Concluding remarks

\section{Introduction}

E-mail: virurobo@savba.sk; phone: +421-907055826.

Abbreviations: $\mathrm{ANDV}=$ Andes virus; $\mathrm{DOBV}=$ Dobrava-Belgrade virus; ETAR = 1- $\beta$-D-ribofuranosyl-3-ethynyl-[1,2,4]triazole; HCPS = hantavirus cardiopulmonary syndrome; HFRS = hemorrhagic fever with renal syndrome; hpi = hours post infection; HTNV = Hantaan virus; $\mathrm{LF}=$ Lactoferrin; $\mathrm{PUUV}=$ Puumala virus; $\mathrm{RBV}=$ Ribavirin; $\mathrm{SEOV}=$ Seoul virus; $\mathrm{SNV}=$ Sin Nombre virus; VLPs $=$ virus-like particles
Hantaviruses (the family Bunyaviridae, the genus Hantavirus) have been discovered more than 35 years ago. They are considered as emerging zoonoses due to their significance as human pathogens and their increasing repetitive appearance during outbreaks. Hantaviruses are causative agents of two human diseases: hemorrhagic fever with renal syndrome (HFRS) in Asia and Europe and hantavirus cardiopulmonary 
syndrome (HCPS) caused by hantavirus species circulating in Americas.

Hantaviruses form enveloped virus particles which contain negative-sense single-stranded RNA genome segmented into the small (S), medium (M), and large (L) segments encoding a nucleocapsid (N) protein, a glycoprotein precursor (GPC), and the viral RNA-dependent RNA polymerase (RdRp), respectively (Schmaljohn and Nichol, 2007).

Hantaviruses are asymptomatically harbored by their reservoir small mammal hosts, mainly rodents. Over the last decade, it became obvious that besides rodents, hantaviruses are carried also by small insectivorous mammals such as shrews, moles, and bats which even seem to be the ancestral hantavirus hosts (Witkowski et al., 2016). Hantaviruses are transmitted by aerosolized excreta (urine, saliva and feces) of their reservoir hosts. A rare way of infection is by bite of the infected animal (Douron et al., 1984). The observation of Andes virus (ANDV) infection in Syrian hamsters indicates that transmission by intragastric administration is also possible, what can mean a potential risk of hantavirus infection by contaminated food (Hooper et al., 2008). Hantaviruses are the only genus within the family Bunyaviridae which is not transmitted by arthropod vectors (Yu and Tesh, 2014).

The most important hantavirus species that cause HFRS in Eurasia are Hantaan virus (HTNV), Puumala virus (PUUV), and Dobrava-Belgrade virus (DOBV) while ANDV and Sin Nombre virus (SNV) are the main causative agents of HCPS in Americas (Table 1) (Klempa et al., 2013). Meanwhile, many other species of hantaviruses have been found, also in Africa, where they could represent a public health threat, as well. The pathogenic and epidemiological potential of the African hantaviruses has not been fully discovered, yet (Klempa et al., 2012). Both, HFRS and HCPS, are acute febrile infections. The incubation time before onset of first symptoms is usually $2-3$ weeks, but there was also reported a range between 1-6 weeks. Common symptoms for HFRS and HCPS in the early phase (3-5 days) of disease are fever, myalgia, malaise, headache, backache and abdominal pain. Nausea and diarrhea appears also often. Hypotension occurs in the next phases (2-7 days) which means also a risk of cardiac failure and death. In HCPS, lung edema appears and leads to lung failure. In contrary, next phases of HFRS are accompanied by renal failure (Krüger et al., 2011). Approximately 150,000 to 200,000 of HFRS cases are hospitalized every year. This number varies depending on epidemic year. The case fatality rate (CFR) of HFRS varies from $<1 \%$ to $12 \%$. There are about 200 cases of HCPS per year with CFR up to 40\% in Americas (Bi et al., 2008; Makary et al., 2010; Hjertqvist et al., 2010; Macneil et al., 2011).

Therapy of hantavirus diseases is usually based on the supportive care such as hemodialysis in HFRS (Bren et al., 1996), mechanical ventilation, extracorporeal membrane oxygenation (Guilfoyle and Macnab, 2008; Wernly et al., 2011) and hemofiltration in HCPS (Bugedo et al., 2016), and/ or shock therapy in both of them. Ribavirin is still the only established drug with approved in vitro and in vivo effects against hantavirus replication (Ogg et al., 2013; Krüger et al., 2011; Westover et al. 2016). In this review, we summarize current approaches to cure and prevent the hantavirus diseases including those not directly targeting the virus but reducing the pathogenesis of the hantavirus infection.

\section{Virus-targeting antivirals}

\subsection{Ribavirin}

Ribavirin (RBV) is a broad-spectrum chemical compound with efficacy against many DNA and RNA viruses, including hantaviruses in vitro and in vivo (Sidwell et al., 1972; Graci et

Table 1. The most important hantaviruses causing hemorrhagic fever with renal syndrome (HFRS) and hantavirus cardiopulmonary syndrome (HCPS)

\begin{tabular}{|c|c|c|c|c|c|}
\hline Virus species & Abbreviation & Disease & Reservoir host & $\begin{array}{l}\text { Geographic } \\
\text { distribution }\end{array}$ & $\begin{array}{c}\text { Case fatality } \\
\text { rate }(\%)\end{array}$ \\
\hline Hantaan virus $^{\mathrm{a}}$ & HTNV & HFRS & Apodemus agrarius & Asia & $10-15$ \\
\hline $\begin{array}{l}\text { Dobrava-Belgrade } \\
\text { virus }^{\mathrm{b}}\end{array}$ & DOBV & HFRS & $\begin{array}{l}\text { Apodemus agrarius } \\
\text { Apodemus flavicollis } \\
\text { Apodemus ponticus }\end{array}$ & Europe & up to 12 \\
\hline Seoul virus ${ }^{c}$ & SEOV & HFRS & $\begin{array}{l}\text { Rattus rattus } \\
\text { Rattus norvegicus }\end{array}$ & worldwide & $1-2$ \\
\hline Puumala virus $^{c}$ & PUUV & HFRS & Myodes glareolus & Europe & $0.1-0.4$ \\
\hline Sin Nombre virus ${ }^{\mathrm{d}}$ & SNV & HCPS & Peromyscus maniculatus & USA, Canada & $30-50$ \\
\hline Andes virus ${ }^{\mathrm{d}}$ & ANDV & HCPS & $\begin{array}{l}\text { Oligoryzomas } \\
\text { longicaudatus }\end{array}$ & $\begin{array}{l}\text { Argentina, Chile, } \\
\text { Uruguay }\end{array}$ & $30-50$ \\
\hline
\end{tabular}

aZeier et al., 2005; Hooper et al., 2006; ' Rizzoli et al., 2015; 'Goeijenbier et al., 2015; 'Jonsson et al., 2008. 
al., 2006). The mechanisms of antiviral activity are based on its ability to inhibit inosine monophosphate dehydrogenase, a crucial enzyme responsible for the synthesis of GTP de novo. Other targets for its antiviral effect have been described, such as capping, translational efficiency of viral mRNA, and a suppressive effect on the viral polymerase activity (Chung et al., 2013). Against hantaviruses, the mechanism of RBV seems to be more likely virus-unspecific. RBV was proved also as a potent mutagen of viral RNA (Crotty et al., 2001, 2002; Jonsson et al., 2005; Chung et al., 2007, 2013).

$\mathrm{RBV}$ was reported to play a role in the immune response by down-regulation of interleukin 10 (IL-10)-producing Treg 1 cells, which could inhibit the conversion of $\mathrm{CD} 4^{+} \mathrm{CD} 25^{-}$ FOXP3- naive $\mathrm{T}$ cells into $\mathrm{CD}^{+}{ }^{+} \mathrm{CD} 25^{+} \mathrm{FOXP}^{+}$adaptive Treg cells to maintain Th1 cell activity. However, the RBVinduced immune response against hantavirus infection is not yet fully discovered as well as the mutagenesis induced by RBV and its influence on next generations of virions (Kobyashi et al., 2012).

The antiviral activity of RBV against HFRS and HCPS associated hantaviruses was tested in vivo and in vitro, as well (Huggins et al., 1986; Chung et al., 2013; Safronetz et al., 2011). RBV-treated suckling mice infected by HTNV showed significantly higher survival rate than the placebo control group (Huggins et al., 1986). A double-blind placebo-controlled test of HFRS Chinese patients resulted in sevenfold lower morbidity and fatal ending in RBV-treated group (Huggins et al., 1991). The rates of oliguria and renal insufficiency are lower after the treatment by RBV, which increases the survival rate. In contrary, RBV used against HCPS seems to be more ineffective (Chapman et al., 1999; Mertz et al., 2004; Chung et al., 2013). Interestingly, RBV

Table 2. List of drugs which could be used against HFRS and HCPS

\begin{tabular}{|c|c|c|c|c|}
\hline \multirow{2}{*}{ Drug } & \multirow{2}{*}{ Target } & \multirow{2}{*}{ Application } & \multicolumn{2}{|c|}{ Commonly reported adverse side-effects } \\
\hline & & & More common & Less common \\
\hline Ribavirin $^{\mathrm{a}}$ & RdRp & $\begin{array}{l}\text { oral (capsule, } \\
\text { solution, tablet), } \\
\text { intravenous } \\
\text { solution, } \\
\text { inhalation } \\
\text { powder for } \\
\text { solution }\end{array}$ & $\begin{array}{l}\text { hemolytic anemia, } \\
\text { decreased hemoglobin, } \\
\text { insomnia, dyspnea, } \\
\text { lack of concentration, } \\
\text { emotional lability and } \\
\text { irritability, nervousness } \\
\text { teratogenicity }\end{array}$ & $\begin{array}{l}\text { depressed mood, } \\
\text { dry skin, feeling } \\
\text { cold, muscle } \\
\text { cramps and } \\
\text { stiffness }\end{array}$ \\
\hline Lactoferrin $^{\mathrm{b}}$ & virus adsorption & oral solution & not observed & $\begin{array}{l}\text { diarrhea, } \\
\text { in very high doses: } \\
\text { skin rash, loss of appetite, } \\
\text { fatigue, chills, constipation }\end{array}$ \\
\hline Favipiravirc $^{c}$ & RdRp & oral tablet & not observed & not observed \\
\hline ETAR $^{\mathrm{d}}$ & RdRp & $\begin{array}{l}\text { not in clinical } \\
\text { use }\end{array}$ & undiscovered & undiscovered \\
\hline Icatibant $^{\mathrm{a}}$ & $\begin{array}{l}\text { bradykinin B2 } \\
\text { receptor }\end{array}$ & $\begin{array}{l}\text { subcutaneous } \\
\text { solution }\end{array}$ & $\begin{array}{l}\text { bleeding, inflammation, } \\
\text { burning, coldness, } \\
\text { pain, redness, stinging, } \\
\text { tingling at the injection site }\end{array}$ & $\begin{array}{l}\text { dizziness } \\
\text { fever }\end{array}$ \\
\hline Methylprednisolone $\mathrm{a}^{\mathrm{a}}$ & $\begin{array}{l}\text { humoral immune } \\
\text { response }\end{array}$ & $\begin{array}{l}\text { oral tablet, } \\
\text { intravenous } \\
\text { solution }\end{array}$ & $\begin{array}{l}\text { aggression, agitation, anxiety, } \\
\text { blurred vision, dizziness, } \\
\text { headache, irritability, } \\
\text { mood changes, nervousness, } \\
\text { irregular pulse, } \\
\text { troubled breathing at rest } \\
\text { pounding in the ears, } \\
\text { weight gain }\end{array}$ & not observed \\
\hline
\end{tabular}

${ }^{\mathrm{a}}$ Compiled from Drugs.com; data sources include Micromedex ${ }^{\circ}$ (updated July 1st, 2016), Cerner Multum ${ }^{\mathrm{TM}}$ (updated July 7th, 2016), Wolters Kluwer ${ }^{\mathrm{TM}}$ (updated July 6th, 2016) and others (Edelson, 1991; Barry et al., 1986; Robertson, 2008; Mertz et al., 2004); Product infromations: Rebetol (ribavirin), Schering-plough Corporation; Virazole (ribavirin), ICN Pharmaceuticals Inc; Copegus (ribavirin), Roche Laboratories. ${ }^{\text {b} C o m p i l e d ~ f r o m ~ W e b M D . c o m ; ~}$ copyrighted data are provided by Natural Medicines Comprehensive Database Consumer Version (FDA, 2003; Harmsen et al., 1995; Ishibashi et al., 2005; Puddu et al., 1998); 'Arias et al., 2014; 'Chung et al., 2008. 
appears to be sufficiently active in treatment of HCPS caused by ANDV (Safronetz et al., 2011).

RBV is associated with potentially serious side effects, such as anemia and the teratogenicity if used in pregnant women (Table 2). Some studies suggest that there is no significant difference in the frequency of adverse events (Mertz et al., 2004). Severe anemia appears in about $10 \%$ of treated patients, therefore a monitoring of hemoglobin is required. In cases of anemia, the reduction of RBV doses is needed, but this can cause compromising of sustained virologic response. Anemia is most probably a consequence of RBV accumulation in erythrocytes due to straight unidirectional transport through the membranes. Nowadays, the only prevention of $\mathrm{RBV}$-induced anemia is the concomitant administration of erythropoietin (Russmann et al., 2006).

\subsection{Lactoferrin}

Lactoferrin (LF), an iron-binding glycoprotein, besides of antibacterial and antifungal effect was reported to have a broad antiviral activity (Bullen and Armstrong, 1978; Masson et al., 1969; Yi et al., 1997). It has been demonstrated that LF also inhibits hantavirus infection in vitro and in vivo (Murphy et al., 2000, 2001).

The antiviral effects of LF against hantaviruses was compared with those of RBV in study which was performed on Vero E6 cells infected by Seoul virus (SEOV). Post infection administration of $100 \mu \mathrm{g} / \mathrm{ml}$ of RBV inhibited the number of foci by $97.5 \%$. $400 \mu \mathrm{g} / \mathrm{ml}$ of LF reduced the number of foci by $85 \%$ in comparison with cells of the control group. In cells pretreated with LF, the number of foci initiated to increase from $24 \mathrm{~h}$ post infection (hpi). LF inhibited viral shedding at $24 \mathrm{hpi}$, but not after $48 \mathrm{hpi}$ (Murphy et al., 2001). Therefore, LF obviously inhibits an early phase of infection, most probably adsorption as indicated in another supportive study (Murphy et al., 2000). Accordingly, the inhibition of hantavirus glycoprotein (G2) expression was observed. By $48 \mathrm{hpi}$, the expression of G2 was increased in both, the control and LF pretreated cells. The complete G2 inhibition was detected only in cells treated with the combination of $\mathrm{LF} / \mathrm{RBV}$ from $12 \mathrm{hr}$ on. The inhibition of adsorption theory is supported also by the fact that LF does not inhibit the expression of hantavirus $\mathrm{G} 2$ and N protein when the infection is just established in cells (Murphy et al., 2001).

On the other hand, RBV actively inhibits viral protein expression within the cell and does not inhibit viral adsorption (Huggins et al., 1984; Streeter et al., 1973). RBV apparently inhibits viral transcription and reduces a massive release of virions from infected cells. Nevertheless, RBV solely is not able to eliminate the virus completely as well as LF. Both, RBV and LF gave significantly higher survival rates in test in vivo. RBV administered $1 \mathrm{hpi}$ to mice at dose of 50 and $25 \mathrm{mg} / \mathrm{kg}$ gave 81.8 and $68.8 \%$ survival rates, respectively (Murphy et al., 2001). These results are well experimentally supported by other studies, too (Huggins et al., 1991). Lactoferrin administered with dose of $160 \mathrm{mg} / \mathrm{kg}$ to mice 1 day prior to hantavirus inoculation had a survival rate of $70 \%$. Double administration of LF enhanced the survival rate. The 160 and $40 \mathrm{mg} / \mathrm{kg}$ double administration resulted in $94.1 \%$ and $85.7 \%$ survival rates, respectively. The difference between single and double administration of LF could be probably due to insufficient adsorption in the single dose or an accumulative effect of LF in the body from the two administrations. Another reason of this difference could be a certain period of time which is necessary for activation of immune system by LF. It has been demonstrated that LF enhances cytotoxic activities of monocytes and NK cells (Murphy et al., 2001).

\subsection{Favipiravir}

Favipiravir (Avigan; T-705; 6-fluoro-3-hydroxy-2-pyrazinecarboxamide) is an antiviral drug selectively inhibiting the RNA-dependent RNA polymerase mainly of influenza virus. Its efficacy against the hantaviruses, Maporal virus, DOBV and Prospect Hill virus was also reported in vivo in mice and hamsters. Its activity in vitro against these hantaviruses was in the range of $5-30 \mu \mathrm{g} / \mathrm{ml}(32-191 \mu \mathrm{mol} / \mathrm{l})$, as calculated by results of FFU reduction assays. (Gowen et al., 2007, 2010; Buys et al., 2011).

Favipiravir decreased detection of viral RNA and reduced infectious titers of SNV and ANDV in vitro. For both, the EC50 was calculated at $\leq 5 \mu \mathrm{g} / \mathrm{ml}(\leq 31.8 \mu \mathrm{mol} / \mathrm{l})$. In hamsters infected with ANDV, favipiravir reached $100 \%$ of effectiveness at preventing lethal HCPS when hamsters were administrated with favipiravir on or before day 4 post exposure. In contrast, animals of the placebo group demonstrated breathing difficulties on day 6 or 7 post infection leading to severe respiratory distress with a fatal outcome by day 9 (Buys et al., 2011; Safronetz et al., 2013).

\subsection{ETAR}

1- $\beta$-D-ribofuranosyl-3-ethynyl- $[1,2,4]$ triazole (ETAR) is a novel, nucleoside analogue. ETAR as well as RBV is a 3 -substituted 1,2,4,-triazole- $\beta$-riboside, but with altered steric and hydrogen bonding capacity. Its mechanism is based on inosine monophosphate dehydrogenase inhibition with reduction of GTP pools, which was combined with residual complementary activity possibly affecting the L protein $(\mathrm{Ku}-$ marapperuma et al., 2007; Goundry et al., 2003).

The antiviral activity of ETAR against HTNV and ANDV as representatives of HFRS and HCPS was approved. The EC50 values for HTNV and ANDV according to FFUreduction assay were $10 \mu \mathrm{mol} / \mathrm{l}$ and $4.4 \mu \mathrm{mol} / \mathrm{l}$, respectively. ETAR was not toxic to Vero E6 cells up to a concentration of $880 \mu \mathrm{mol} / \mathrm{l}$. Moreover, ETAR protected suckling mice from 
HTNV infection at similar degree as RBV. The evaluation of ETAR in the suckling mice model infected by HTNV showed that the in vivo antiviral activity of ETAR at the 12.5 and $25 \mathrm{mg} / \mathrm{kg}$ doses was similar to that of $50 \mathrm{mg} / \mathrm{kg} \mathrm{RBV}$ (Chung et al., 2008).

As shown previously, RBV is responsible for increased frequency of errors during replication of the HTNV leading to increased mutation frequency. Although ETAR is structurally similar to RBV, a comparison to the placebo-treated HTNV group showed no significant change in mutation frequency caused by ETAR. The metabolites of ETAR accumulate to lower concentrations in cells than the metabolites of RBV, which means that ETAR metabolites interact more potently with targets than the metabolites of RBV. ETAR is not expected to induce mutations probably due to its lack of pseudo-base pair presence (Chung et al., 2008).

\subsection{Virus fusion inhibition}

The target of interest of another study was G2 envelope glycoprotein, which plays a role of the viral fusion protein. It seems to be similar with other molecules of class II fusion proteins, as suggested in silico and in vitro analyses (Cifuentes-Muñoz et al., 2011; Tischler et al., 2005). Its ectodomain is composed of three domains which are connected by a stem to the anchor in the viral envelope. It has been shown, that these fusion proteins could be inhibited by protein fragments spanning domain III (DIII) and the stem region. For this reason, recombinant ANDV DIII and stem peptides were synthesized and expected to inhibit membrane fusion and cell entry. Combination of DIII and the C-terminal part of stem region inhibited the infection of Vero E6 by ANDV up to $60 \%$ during the endosomal route of ANDV. When fusion of ANDV occurred at the plasma membrane, infection was inhibited over 95\%. According to these results, a strategy using hantavirus stem fragments may obviously inhibit fusion of similar viruses within the same genus (Barriga et al., 2016).

\subsection{Immunotherapy}

Presently, there are no published reports of controlled clinical use of immunotherapy for HFRS and HCPS in humans. Some studies in animal models (hamsters, mice and rats) indicated that passive administration of neutralizing antibodies (Abs) or polyclonal sera to HTNV can sufficiently protect animals from disease involved with the same species of virus (Zhang et al., 1989; Arikawa et al., 1992; Xu et al., 2002). Anti-HTNV G2-specific neutralizing Abs administrated 4 dpi sufficiently protected hamsters and up to 2 dpi protected suckling mice from lethal outcome (Linag et al., 1996; Xu et al., 2002). Post-exposure administration of neutralizing Abs was demonstrated against HCPS-causing hantaviruses, as well. Immune plasma obtained from HCPS patients infected by ANDV and SNV protected hamsters and deer mice infected by homologous virus, respectively (Custer et al., 2003; Medina et al., 2007).

\section{Host-targeting antivirals}

\subsection{Corticosteroid therapy}

High levels of proinflammatory cytokines, especially TNF- $\alpha$ were detected in sera of patients with HFRS and HCPS. TNF- $\alpha$ is released by neutrophils, NK cells, $\mathrm{CD}^{+} \mathrm{T}$ cells as well as DC and macrophages infected by a hantavirus (Schönrich et al., 2015; Kilpatrick et al., 2004). An immunomodulatory treatment was firstly performed and evaluated during the Korean war, when oral or intramuscular application of corticoids reduced lethal cases of HFRS due to the shock, but the mortality was not decreased at all (Sayer et al., 1955).

A retrospective analysis of 22 HCPS patients in Chile noted that high-dose methylprednisolone treatment reduced mortality during the shock (Tapia et al., 2000). Another study involved 60 Chilean patients with HCPS caused by ANDV. This study reported a phase 2 , double-blind, placebo-controlled clinical trial to evaluate the parameters such as the safety and the efficacy of intravenously applied methylprednisolone in patients with HCPS in Chile. The treatment of HCPS with high-dose methylprednisolone seems to be safe, but it is not recommended for clinical use, because there was no significant difference in lethal outcome between the methylprednisolone recipients ( 8 of 30 patients - 27\%) and placebo recipients (12 of 30 patients $-40 \%$ ) (Vial et al., 2013).

\subsection{Host-cell hantavirus-binding receptor inhibitors}

Pathogenic hantaviruses attach to the surface of host cells using their $\alpha_{v} \beta_{3}$ integrins. For this reason, a couple of synthesized cyclic nonapeptides, CLVRNLAWC and CQAT TARNC were designed, and found to inhibit SNV infection in vitro at a $4: 1$ nanoparticle-to-virus ratio $(9.0 \%$ to $32.5 \%$ and $27.6 \%$ to $37.6 \%$, respectively). CQATTARNC used at a 20:1 ratio, inhibited infection by $50 \%$ (Hall et al., 2008). Another peptidomimetic compounds were chosen on the base of their molecular structure and possible ability to bind $\alpha_{v} \beta_{3}$ cell receptor. Forty nine peptidomimetic molecules in the first round and 68 molecules in the second round of screening with antihantavirus effect in the two thousand lower micromolar range were identified. In result, a unique set of chemical compounds for the next phases of the drug discovery development was obtained. Their antiviral potential needs to be refined and supported by in vivo studies (Hall et al., 2010). 


\subsection{Therapy via blocking of bradykinin $B 2$ receptor}

Another promising idea for the therapy of hantavirus diseases is the use of bradykinin receptor antagonists. Increased capillary permeability and vascular leakage are typical for all hantavirus infections. Complement activation seems to be linked to vascular changes in PUUV infections. The mechanisms behind the changes of vascular permeability after hantavirus infection are obviously a multifactorial event which is not yet completely described. It has been found that hantaviruses are responsible for increased activation of the kinin-kallikrein system during the infection of endothelial cells, resulting in the liberation of bradykinin (Bossi et al., 2004; Golias et al., 2007; Taylor et al., 2013).

Bradykinin is a nonapeptide binding bradykinin B2 receptor in role of an inflammatory mediator which is responsible for a dilatation of the blood vessels, increased vascular permeability and subsequently causes the blood pressure to fall. Icatibant is a peptidomimetic drug which is a selective antagonist of bradykinin B2 receptors. Icatibant blocks the binding of bradykinin to the bradykinin B2 receptor by binding to this receptor itself (Taylor et al., 2013).

A case report described a 37-year-old Finnish male patient with severe PUUV infection successfully treated with a single dose of icatibant (Antonen et al., 2013; Vaheri et al., 2014). A report of another case, a 67-year-old female patient with severe HFRS caused by PUUV described a patient with a malignant chronic lymphoproliferative disease mostly affecting the spleen. In addition, patients' blood disease was morphologically considered as either atypical chronic lymphotic leukemia (CLL) or splenic marginal zone lymphoma. The 2 day delay between the doses the icatibant had no significant role in the recovery. Although this patient did not die, the icatibant did not play the role in recovery. Icatibant was not sufficient probably due to an extremely severe case of PUUV infection. It can be useful to note that one of the predictions of severity of disease is a spleen with abnormalities. Nevertheless, the bradykinin $\mathrm{B} 2$ receptor antagonist icatibant is surely worth a further study as a target in the treatment of severe hantavirus infections (Laine et al., 2015).

\section{Vaccines}

There are no Food and Drug Administration (FDA)licensed vaccines for HFRS or HCPS. Some vaccines based on use of immunoactive inactivated virus particles are in use in Far East, particularly in China and Korea. Other approaches of vaccine development were also studied and evaluated. Recently, some excellent review articles about vaccines against hantaviruses have been already published (Maes et al., 2009; Schmaljohn, 2009, 2012; Krüger et al., 2011), so we focused mostly on the most recent highlights.

\subsection{Inactivated virus vaccines}

Anti-hantavirus inactivated vaccines used in China and Korea are generally inactivated by formalin or $\beta$-propiolactone. These vaccines are aimed to protect against the hantaviruses HTNV, SEOV and PUUV, which are causing most of the cases of HFRS (Zhang et al., 2010). Hantavax $^{\mathrm{TM}}$, a formalin-inactivated vaccine developed in Korea consists HTNV amplified in mouse brains. It is commonly used since 90's in Korea and China. Hantavax ${ }^{\mathrm{TM}}$ showed immunogenicity lasting at least two years with a three-dose schedule. The protective neutralizing antibody response showed to be sufficient just after third boosting dose (Song et al., 2016).

Except of China and Korea, the research of anti-hantavirus vaccines was established also in Russia. An inactivated bivalent PUUV/DOBV vaccine consisting the hantavirus strains PUUV Ufa-97 and DOBV-Aa Lipetzk-06 was developed. The aluminium hydroxide was used as adjuvant. This vaccine showed a significant neutralizing antibody activity against both PUUV and DOBV in immunized $\mathrm{BALB} / \mathrm{c}$ mice. This bivalent vaccine against PUUV and DOBV passed pre-clinical tests under the Russian control authority institution and seems to be a promising approach in prevention against these species of hantaviruses (Krüger et al., 2011).

Recently, there are no studies about using of live attenuated hantaviruses for humans. Meanwhile, it has been proposed that a genetic reassortant of pathogenic and non-pathogenic virus species could be a feasible vaccine development. A particle from the $\mathrm{S}$ and $\mathrm{L}$ segments of Prospect Hill virus and the $\mathrm{M}$ segment of PUUV was constructed. This virus particle interacted with elements of the innate immune system in vitro as Prospect Hill virus, but because of the PUUV origin of the M segment is expected to induce anti-PUUV neutralizing immune response (Handke et al., 2010).

\subsection{Chimeric molecular vaccines}

Non-replicating adenovirus vectors showed to be good carriers for a development of recombinant vaccines against hantaviruses ANDV and SEOV as representatives of HCPS and HFRS causing hantaviruses. Adenovirus expressing ANDV N, G1 or G2 proteins sufficiently protected the hamsters against lethal outcome of infection with ADNV (Safronetz et al., 2009). Another model of a replicationcompetent recombinant canine adenovirus type 2 expressing the G1 protein of SEOV (rCAV-2-G1) in BALB/c mice was evaluated. Sera from immunized mice contained antibodies which specifically recognized SEOV and neutralized it in vitro. The recombinant virus completely protected the animals against a lethal challenge with the highly virulent strain of SEOV-CC-2 (Yuan et al., 2009). 


\subsection{Virus-like particles}

Virus-like particles (VLPs), such as hepatitis B virus and polyomavirus core particles, are viral proteins carrying foreign epitopes (Ulrich et al., 1998). HTNV-VLPs by co-expressing HTNV N protein and G1 and G2 glycoproteins in Chinese hamster ovary $(\mathrm{CHO})$ cells were generated. Then, intramuscular and subcutaneous administrations of HTNV-VLPs were compared for the ability to induce a specific immune response against HTNV infection in mice. The vaccination with HTNV-VLPs resulted in the induction of higher levels of specific cellular immune response to $\mathrm{N}$ protein in contrast with inactivated vaccine (Li et al., 2010). It has been shown that more species of hantaviruses (ANDV and PUUV) are potent to form VLPs just from G1 and G2 glycoproteins which are pleomorphic and expose protrusions. The viral nucleoprotein was not required for particle formation. These characteristics can be used for inducing of specific immune response for different species of hantaviruses (Acuña et al., 2014).

\subsection{DNA vaccines}

Different types of DNA vaccines against HTNV, SEOV, PUUV, ANDV and SNV using linear DNA, plasmid DNA and alphavirus replicons carrying genes for $\mathrm{N}$ protein and/or glycoproteins have been made. Interestingly, their immunogenicity apparently differs in different animal models. The $\mathrm{M}$ segment of ANDV was presented as immunogenic in nonhuman primates and rabbits but not in hamsters (Hammerbeck et al., 2009). Three groups of nine volunteers were vaccinated with DNA vaccines for HTNV, PUUV or with a mixture of both vaccines expressing G1 and G2 genes of these viruses within the phase I study. Hantavirus neutralizing antibodies were detected in five of nine and seven of nine persons who received all three vaccinations with the HTNV or PUUV DNA vaccine. In case of combined vaccine group, seven of the nine participants after all three vaccinations developed antibodies against PUUV. The three strongest responders to the PUUV vaccine had a strong neutralizing response to the HTNV, too. Both, HTNV and PUUV DNA vaccines were immunogenic, but when mixed, more individuals responded to the PUUV in contrast to the HTNV DNA vaccine (Hooper et al., 2014). DNA vaccines protecting from hantaviruses causing HCPS were demonstrated on geese which were vaccinated with an ANDV DNA vaccine encoding the virus envelope glycoproteins for a purpose to produce neutralizing antibodies for use in humans because availability of convalescent plasma from survivors is very limited. Geese are supposed to produce IgY and alternatively spliced IgY $\Delta \mathrm{Fc}$, that can be purified at high concentrations from egg yolks. IgY lacks the mammalian Fc that can create antibodies in horses, sheep, and rabbits reactogenic in humans. All geese developed a high-titer neutralizing antibodies after second vaccination. It was shown by a pseudovirion neutralization assay (PsVNA) that high level of these neutralizing antibodies were maintained for over 1 year. Moreover, a booster vaccination resulted in higher levels of neutralizing antibodies (i.e., PsVNA ${ }_{80}$ titers $>100,000$ ). The protective efficacy of the sera was proved in hamster model of lethal HCPS. It was shown that $\mathrm{IgY} / \mathrm{IgY} \Delta \mathrm{Fc}$ purified from eggs transferred to hamsters subcutaneously starting 5 days after IM challenge with ANDV (25 $\mathrm{LD}_{50}$ ) protected 7 of 8 hamsters. As it was shown, DNA vaccine/goose platform is obviously a good candidate of preventing a lethal HCPS when administered post-exposure (Haese et al., 2015).

\section{Concluding remarks}

Hantaviruses threaten the people throughout the world by serious diseases. Instead of the only available antiviral drug Ribavirin against the hantaviruses, there are some other promising approaches under development which could significantly sustain the antiviral efficacy of Ribavirin and decrease the lethal endings of both, HFRS and HCPS. The combination therapy of RBV and any other antiviral compound could be apparently more effective in therapy of hantavirus infections than the discrete usage of only one of them. The use of nucleoside and pyrazine derivates as well as peptide derivates binding the cellular $\alpha_{v} \beta_{3}$ integrins, the receptors for adsorption of pathogenic hantaviruses could be another kind of effective therapy. However, a development of efficient and safe vaccines seems to be the best option to prevent the dangerous hantavirus diseases.

Acknowledgements. I greatly appreciate the critical reading by B. Klempa (Institute of Virology, Biomedical Research Center Slovak Academy of Sciences, Bratislava, Slovakia and Institute of Virology, Helmut-Ruska-Haus, Charité School of Medicine, Berlin, Germany).

\section{References}

Acuña R, Cifuentes-Mu-oz N, Márquez CL, Bulling M, Klingström J, Mancini R, Lozach PY, Tischler ND. J. Virol. 88, 23442348, 2014. https://doi.org/10.1128/JVI.03118-13

Antonen J, Leppänen I, Tenhunen J, Arvola P, Mäkelä S, Vaheri A., Mustonen J. Scand. J. Infect. Dis. 45, 494-496, 2013. https://doi.org/10.3109/00365548.2012.755268

Arias A, Thorne L, Goodfellow I. Elife 21, e03679, 2014.

Arikawa J, Yao JS, Yoshimatsu K, Takashima I, Hashimoto N. Arch. Virol. 126, 271-281, 1992. https://doi.org/10.1007/ BF01309700

Barriga GP, Villalón-Letelier F, Márquez CL, Bignon EA, Acu-a R, Ross BH, Monasterio O., Mardones GA, Vidal SE, Tischler ND. PLoS Negl. Trop. Dis. 10, e0004799, 2016. https:// doi.org/10.1371/journal.pntd.0004799 
Barry W, Cockburn F, Cornall R, Price JF, Sutherland G, Vardag A. Arch. Dis. Child. 61, 593-597, 1986. https://doi. org/10.1136/adc.61.6.593

Bi Z, Formenty PB, Roth CE. J. Infect. Dev. Ctries. 2, 3-23, 2008. https://doi.org/10.3855/jidc.317

Bossi F, Fischetti F, Pellis V, Bulla R, Ferrero E, Mollnes TE, Regoli D, Tedesco F. J. Immunol. 173, 6921-6927, 2004. https:// doi.org/10.4049/jimmunol.173.11.6921

Bren AF, Pavlovcic SK, Koselj M, Kovac J, Kandus A, Kveder R. Ren. Fail. 18, 635-638, 1996. https://doi. org $/ 10.3109 / 08860229609047688$

Bugedo G, Florez J, Ferres M, Roessler E, Bruhn A. Rev. Bras. Ter. Intensiva 28, 190-194, 2016. https://doi.org/10.5935/0103507X.20160032

Bullen JJ, Armstrong JA. Immunology 36, 781-791, 1978.

Buys KK, Jung KH, Smee DF, Furuta Y, Gowen BB. Antivir. Chem. Chemother. 21, 193-200, 2011. https://doi.org/10.3851/ IMP1729

Chapman LE, Mertz Gj, Peters CJ, Jolson HM, Khan AS, Ksiazek TG, Koster FT, Baum KF, Rollin PE, Pavia AT, Holman RC, Christenson JC, Rubin PJ, Behrman RE, Bell LJ, Simpson GL, Sadek RF. Antivir. Ther. 4, 211-219, 1999.

Chung DH, Kumarapperuma SC, Sun Y, Li Q, Chu YK, Arterburn JB, Parker WB, Smith J, Spik K, Ramanathan HN, Schmaljohn CS, Jonsson CB. Antiviral Res. 79, 19-27, 2008. https://doi.org/10.1016/j.antiviral.2008.02.003

Chung DH, Sun Y, Parker WB, Arterburn JB, Bartolucci A, Jonsson CB. J. Virol. 81, 11722-11729, 2007. https://doi. org/10.1128/JVI.00874-07

Chung DH, Västermark Å, Camp JV, McAllister R, Remold SK, Chu YK, Bruder C, Jonsson CB. J. Virol. 87, 10997-11007, 2013. https://doi.org/10.1128/JVI.01394-13

Cifuentes-Mu-oz N, Barriga GP, Valenzuela PDT, Tischler ND. J. Gen. Virol. 92, 552-63, 2011. https://doi.org/10.1099/ vir.0.027235-0

Crotty S, Cameron C, Andino R. J. Mol. Med. (Berlin) 80, 86-95, 2002. https://doi.org/10.1007/s00109-001-0308-0

Crotty S, Cameron CE, Andino R. Proc. Natl. Acad. Sci. USA 98, 6895-6900, 2001. https://doi.org/10.1073/ pnas. 111085598

Douron E, Moriniere B, Matheron S, Girard PM, Gonzales JP, Hirsch F, McCormick JB. Lancet 24, 676-677, 1984. https:// doi.org/10.1016/S0140-6736(84)92187-1

Edelson PJ. Pediatr. Infect. Dis. 10, 82, 1991. https://doi. org/10.1097/00006454-199101000-00022

Food and Drug Administration, CFSAN/Office of Food Additive Safety. Agency Response Letter GRAS Notice No. GRN 000130. 2003. Available at: http://www.cfsan.fda. gov/ rdb/opa-g130.html.

Goeijenbier M, Verner-Carlsson J, van Gorp EC, Rockx B, Koopmans MP, Lundkvist Å, van der Giessen JW, Reusken CB. Neth. J. Med. 73, 155-160, 2015.

Golias Ch, Charalabopoulos A, Stagikas D, Charalabopoulos K, Batistatou A. Hippokratia. 11, 124-8, 2007.

Goundry WRF, Baldwin JE, Lee V. Tetrahedron 59, 1719-1729, 2003. https://doi.org/10.1016/S0040-4020(03)00115-7

Gowen BB, Wong MH, Jung KH, Sanders AB, Mendenhall M, Bailey KW, Furuta Y, Sidwell RW. Antimicrob. Agents
Chemother. 51, 3168-3176, 2007. https://doi.org/10.1128/ AAC.00356-07

Gowen BB, Wong MH, Jung KH, Smee DF, Morrey JD, Furuta Y. Antiviral Research 86, 121-127, 2010. https://doi. org/10.1016/j.antiviral.2009.10.015

Graci JD, Cameron CE. Rev. Med. Virol. 16, 37-48, 2006. https:// doi.org/10.1002/rmv.483

Guilfoyle JF, Macnab AJ. Air. Med. J. 27, 299-302, 2008. https:// doi.org/10.1016/j.amj.2008.08.003

Haese N, Brocato RL, Henderson T, Niles ML, Kwilas SA, Josleyn MD, Hammerbeck CD, Schiltz J, Royals M, Ballantyne J, Hooper JW, Bradley DS. PLoS Negl. Trop. Dis. 9, e0003803, 2015. https://doi.org/10.1371/journal. pntd.0003803

Hall PR, Hjelle B, Brown DC, Ye C, Bondu-Hawkins V, Kilpatrick KA, Larson RS. Antimicrob. Agents Chemother. 52, 20792088, 2008. https://doi.org/10.1128/AAC.01415-07

Hall PR, Leitão A, Ye C, Kilpatrick K, Hjelle B, Oprea TI, Larson RS. Bioorg. Med. Chem. Lett. 20, 7085-7091, 2010. https:// doi.org/10.1016/j.bmcl.2010.09.092

Hammerbeck CD, Wahl-Jensen V, Hooper JW. In Barrett ADT, Stanberry LR, Eds. London: Academic Press/Elsevier; 379-412, 2009.

Handke W, Oelschlegel R, Franke R, Wiedemann L, Krüger DH, Rang A. J. Gen. Virol. 91, 2351-2359, 2010. https://doi. org/10.1099/vir.0.021139-0

Harmsen MC, Swart PJ, de Béthune MP, Pauwels R, De Clercq E, The TH, Meijer DK. J. Infect. Dis. 172, 380-388, 1995. https://doi.org/10.1093/infdis/172.2.380

Hjertqvist M, Klein SL, Ahlm C, Klingström J. Emerg. Infect. Dis. 16, 1584-1586, 2010. https://doi.org/10.3201/ eid1610.100242

Hooper JW, Custer DM, Smith J, Wahl-Jensen V. Virology 347, 208 216, 2006. https://doi.org/10.1016/j.virol.2005.11.035

Hooper JW, Ferro AM, Wahl-Jensen V. J. Virol. 82, 1332-1338, 2008. https://doi.org/10.1128/JVI.01822-07

Hooper JW, Moon JE, Paolino KM, Newcomer R, McLain DE, Josleyn M, Hannaman D, Schmaljohn C. Clin. Microbiol. Infect. 20, 110-117, 2014. https://doi.org/10.1111/1469-0691.12553

Huggins JW, Hsiang CM, Cosgriff TM, Guang MY, Smith JI, Wu ZO, LeDuc JW, Zheng ZM, Meegan JM, Wang QN. J. Infect. Dis. 164, 1119-1127, 1991. https://doi.org/10.1093/ infdis/164.6.1119

Huggins JW, Kim GR, Brand OM, McKee KT Jr. J. Infect. Dis. 153, 489-497, 1986. https://doi.org/10.1093/infdis/153.3.489

Huggins JW, Robins RK, Canonico PG. Antimicrob. Agents Chemother. 26, 476-480, 1984. https://doi.org/10.1128/ AAC.26.4.476

Ishibashi Y, Takeda K, Tsukidate N, Miyazaki H, Ohira K, DosakaAkita H, Nishimura M. Hepatol. Res. 32, 218-23, 2005. https://doi.org/10.1016/j.hepres.2005.03.018

Jonsson CB, Hooper J, Mertz G. Antiviral Res. 78, 162-169, 2008. https://doi.org/10.1016/j.antiviral.2007.10.012

Jonsson CB, Milligan BG, Arterburn JB. Virus Res. 107, 195-205, 2005. https://doi.org/10.1016/j.virusres.2004.11.009

Kilpatrick ED, Terajima M, Koster FT, Catalina MD, Cruz J, Ennis FA. J. Immunol. 172, 3297-3304, 2004. https://doi. org/10.4049/jimmunol.172.5.3297 
Klempa B, Radosa L, Krüger DH. Acta Virol. 57, 130-137, 2013. https://doi.org/10.4149/av 2013 02_130

Klempa B, Witkowski PT, Popugaeva E, Auste B, Koivogui L, Fichet-Calvet E, Strecker T, Ter Meulen J, Krüger DH. J. Virol. 86, 3819-3827, 2012. https://doi.org/10.1128/ JVI.05879-11

Kobyashi T, Nakatsuka K, Shimizu M, Tamura H, Shinya E, Atsukawa M, Takahashi H, Sakamoto C. Immunology. 137, 259-270, 2012. https://doi.org/10.1111/imm.12005

Krüger DH, Figueiredo L T, Song J W, Klempa B. J. Clin. Virol. 64,128-136, 2015. https://doi.org/10.1016/j. jcv.2014.08.033

Krüger DH, Schönrich G, Klempa B. Hum. Vaccines 7, 1-9, 2011. https://doi.org/10.4161/hv.7.6.15197

Kumarapperuma SC, Sun Y, Jeselnik M, Chung K, Parker WB, Jonsson CB, Arterburn JB. Bioorg. Med. Chem. Lett. 17, 32033207, 2007. https://doi.org/10.1016/j.bmcl.2007.03.018

Laine O, Leppänen I, Koskela S, Antonen J, Mäkelä S, Sinisalo M, Vaheri A, Mustonen J. Infect. Dis. (London) 47, 107-111, 2015.

Li C, Liu F, Liang M, Zhang Q, Wang X, Wang T, Li J, Li D. Vaccine 28, 4294-4300, 2010. https://doi.org/10.1016/j. vaccine. 2010.04.025

Macneil A, Nichol ST, Spiropoulou CF. Virus Res. 162, 138-147, 2011. https://doi.org/10.1016/j.virusres.2011.09.017

Maes P, Clement J, Van Ranst M. Expert Rev. Vaccines 8, 67-76, 2009. https://doi.org/10.1586/14760584.8.1.67

Makary P, Kanerva M, Ollgren J, Virtanen MJ, Vapalahti O, Lyytikäinen O. Epidemiol. Infect. 138, 1484-1492, 2010. https://doi.org/10.1017/S0950268810000087

Masson PL, Heremans JF, Schonne E. J. Exp. Med. 130, 643-658, 1969. https://doi.org/10.1084/jem.130.3.643

Mertz GJ, Miedzinski L., Goade D., Pavia AT, Hjelle B, Hansbarger CO, Levy H, Koster FT, Baum K, Lindemulder A, Wang W, Riser L, Fernandez H, Whitley RJ, Collaborative Antiviral Study Group. Clin. Infect. Dis. 39, 1307-1313, 2004. https://doi.org/10.1086/425007

Murphy ME, Kariwa H, Mizutani T, Tanabe H, Yoshimatsu K, Arikawa J, Takashima I. J. Vet. Med. Sci. 63, 637-645, 2001. https://doi.org/10.1292/jvms.63.637

Murphy ME, Kariwa H, Mizutani T, Yoshimatzu K, Arikawa J, Takashima I. Arch. Virol. 145, 1571-1582, 2000. https:// doi.org/10.1007/s007050070077

Ogg M, Jonsson CB, Camp JV, Hooper JW. Viruses. 5, 2704-2720, 2013. https://doi.org/10.3390/v5112704

Puddu P, Borghi P, Gessani S, Valenti P, Belardelli F, Seganti L. Int. J. Biochem. Cell Biol. 30, 1055-1062, 1998. https://doi. org/10.1016/S1357-2725(98)00066-1

Rizzoli A, Tagliapietra V, Rosà R, Hauffe HC, Marini G, Voutilainen L, Sironen T, Rossi C, Arnoldi D, Henttonen H. Epidemiol. Infect. 143, 2241-2244, 2015. https://doi. org/10.1017/S0950268814003525

Robertson M. BMJ. 336, 505, 2008. https://doi.org/10.1136/ bmj.39457.828287.47

Russmann S, Grattagliano I, Portincasa P, Palmieri VO, Palasciano G. Curr. Med. Chem. 13, 3351-3357, 2006. https://doi. org/10.2174/092986706778773059
Safronetz A, Haddock E, Feldmann F, Hideki E, Feldmann H. PLoS One. 6, e23560, 2011. https://doi.org/10.1371/journal. pone. 0023560

Safronetz D, Falzarano D, Scott DP, Furuta Y, Feldmann H, Gowen BB. Antimicrob. Agents Chemother. 57, 4673-4680, 2013. https://doi.org/10.1128/AAC.00886-13

Safronetz D, Hedge NR, Ebihara H, Denton M, Kobinger GP, St Jeor S, Feldmann H, Johnson DC. J. Virol. 83, 7285-7295, 2009. https://doi.org/10.1128/JVI.00373-09

Sayer WJ, Entwhisle G, Uyeno B, Bignall RC. Ann. Intern. Med. 42, 839-851, 1955. https://doi.org/10.7326/0003-481942-4-839

Schmaljohn C. Vaccine 5, 27, 2009.

Schmaljohn CS. Expert Rev. Vaccines 11, 511-513, 2012. https:// doi.org/10.1586/erv.12.15

Schmaljohn CS, Nichol ST. In Knipe DM and Howley PM, Eds. Fields Virology. Philadelphia: Lippencott Williams \& Wilkins 5, 1741-189, 2007.

Schönrich G, Krüger DH, Raftery MJ. Front. Microbiol. 6, 222, 2015.

Sidwell RW, Huffman JH, Khare GP, Allen LB, Witkowski JT, Robins RK. Science. 177, 705-706, 1972. https://doi.org/10.1126/ $\underline{\text { science.177.4050.705 }}$

Song JY, Woo HJ, Cheong HJ, Noh JY, Baek LJ, Kim WJ. Vaccine. 34, 1289-1295, 2016. https://doi.org/10.1016/j. vaccine.2016.01.031

Streeter DG, Witkowski JT, Khare GP, Sidwell RW, Bauer RJ, Robins RK, Simon. Proc. Nat. Acad. Sci. USA 4, 1174-1178, 1973. https://doi.org/10.1073/pnas.70.4.1174

Tapia M, Mansilla C, Vera J. Rev. Chil. Infect. 17, 258-269, 2000. https://doi.org/10.4067/S0716-10182000000300010

Taylor SL, Wahl-Jensen V, Copeland AM, Jahrling PB, Schmaljohn CS. PLoS Pathog. 9, e1003470, 2013. https://doi. org/10.1371/journal.ppat.1003470

Tischler ND, Gonzalez A, Perez-Acle T, Rosemblatt M, Valenzuela PD. J. Gen. Virol. 86, 2937-2947, 2005. https://doi. org/10.1099/vir.0.81083-0

Ulrich R, Nassal M, Meisel H, Krüger DH. Adv. Virus. Res. 50, 141-182, 1998. https://doi.org/10.1016/S0065-3527(08)60808-8

Vaheri A, Strandin T, Jääskeläinen AJ, Vapalahti O, Jarva H, Lokki ML, Antonen J, Leppänen I, Mäkelä S, Meri S, Mustonen J. Antiviral Res. 111, 23-25, 2014. https://doi.org/10.1016/j. antiviral.2014.08.007

Vial PA, Valdivieso F, Ferres M, Riquelme R, Rioseco ML, Calvo M, Castillo C, Díaz R, Scholz L, Cuiza A, Belmar E, Hernandez C, Martinez J, Lee SJ, Mertz GJ; Hantavirus Study Group in Chile. Clin. Infect. Dis. 57, 943-951, 2013. https://doi.org/10.1093/cid/cit394

Wernly JA, Dietl CA, Tabe CE, Pett SB, Crandall C, Milligan K, Crowley MR. Eur. J. Cardiothorac. Surg. 40, 1334-1340, 2011. https://doi.org/10.1016/j.ejcts.2011.01.089

Westover JB, Sefing EJ, Bailey KW, Van Wettere AJ, Jung KH, Dagley A, Wandersee L, Downs B, Smee DF, Furuta Y, Bray M, Gowen BB. Antiviral Res. 126, 62-68, 2016. https://doi. org/10.1016/j.antiviral.2015.12.006

Witkowski PT, Drexler JF, Kallies R, Ličková M, Bokorová S, Mananga GD, Szemes T, Leroy EM, Krüger DH, Drosten C, 
Klempa B. Infect. Genet. Evol. 41, 113-119, 2016. https:// doi.org/10.1016/j.meegid.2016.03.036

Xu Z, Wei L, Wang L, Wang H, Jiang S. Biochem. Biophys. Res. Commun. 298, 552-558, 2002. https://doi.org/10.1016/ S0006-291X(02)02491-9

Yi M, Kaneko S, Yu DY, Murakami S. J. Virol. 71, 5997-6002, 1997. Yu XJ, Tesh RB. J. Infect. Dis. 210, 1693-1699, 2014. https://doi. org/10.1093/infdis/jiu336

Zeier M, Handermann M, Bahr U, Rensch B, Müller S, Kehm R, Muranyi W, Darai G. Virus Genes 30, 157-180, 2005. https://doi.org/10.1007/s11262-004-5625-2
Zhang XK, Takashima I, Hashimoto N. Arch. Virol. 105, 235-246, 1989. https://doi.org/10.1007/BF01311360

Zhang YZ, Zou Y, Fu ZF, Plyusnin A. Emerg. Infect. Dis. 16, 11951203, 2010. https://doi.org/10.3201/eid1608.090470

"Multum Information Services, Inc. Expert Review Panel".

"Product Information. Copegus (ribavirin)." Roche Laboratories, Nutley, NJ.

"Product Information. Rebetol (ribavirin)." Schering-Plough Corporation, Kenilworth, NJ.

"Product Information. Virazole (ribavirin)." ICN Pharmaceuticals Inc, Cost Mesa, CA. 